\title{
The effect of drinking milk containing conjugated linoleic acid on fecal microbiological profile, enzymatic activity, and fecal characteristics in humans
}

\author{
Edward R Farnworth*1, Yvan P Chouinard ${ }^{2}$, Helene Jacques², \\ Sudha Venkatramanan ${ }^{3}$, Akier A Maf ${ }^{1}$, Sabrina Defnoun ${ }^{1}$ and Peter JH Jones ${ }^{3}$
}

Address: ${ }^{1}$ Food Research and Development Centre, Agriculture Canada, Saint Hyacinthe, Quebec, Canada, ${ }^{2}$ Departments of Animal Science and Food Science and Nutrition, Laval University, Quebec City, Quebec, Canada and ${ }^{3}$ School of Dietetics and Human Nutrition, McGill University, Montreal, Quebec, Canada

Email: Edward R Farnworth* - farnworthed@agr.gc.ca; Yvan P Chouinard - Yvan.Chouinard@san.ulaval.ca;

Helene Jacques - helene.Jacques@aln.ulaval.ca; Sudha Venkatramanan - venkatramanan_sudha@yahoo.ca; Akier A Maf - mafuaa@agr.gc.ca;

Sabrina Defnoun - sdefnoun2@yahoo.fr; Peter JH Jones - Peter_Jones@umanitoba.ca

* Corresponding author

Published: 9 July 2007

Nutrition Journal 2007, 6:15 doi:10.1186/1475-2891-6-15

This article is available from: http://www.nutritionj.com/content/6/I/I5

(c) 2007 Farnworth et al; licensee BioMed Central Ltd.

This is an Open Access article distributed under the terms of the Creative Commons Attribution License (http://creativecommons.org/licenses/by/2.0), which permits unrestricted use, distribution, and reproduction in any medium, provided the original work is properly cited.
Received: 5 December 2006

Accepted: 9 July 2007

\begin{abstract}
Background: The primary objective was to determine whether consumption of conjugated linoleic acids (CLAs) affected the fecal microbiota composition, fecal enzyme activity or fecal composition.

Methods: Human subjects consumed (I L/day) cows' milk ( $4 \%$ fat) containing ( $5 \mathrm{mg} / \mathrm{g}$ fat) cis-9, trans-I I CLA (CONT), (32 mg/g fat) cis-9, trans-I I CLA (NAT) and (32 mg/g fat) trans- 10 , cis- 12 CLA and cis-9, trans-II CLA (SYN) for 8 weeks, in addition to their normal diet. Milk feeding periods were separated by 4 week washout periods. Fecal samples were obtained at the beginning (day 0 ) and the end (day 56) of each milk feeding period. Fecal samples were analysed for microbiological profile, enzyme activity, $\mathrm{pH}$ and short chain fatty acid content.

Results: Samples taken at day 0 and day 56 indicated that the numbers of lactobacilli and bifidobacteria significantly decreased after consumption of all experimental milks; total aerobes, total anaerobes, enterobacteria, and enterococci + streptococci did not change. At day 56, the activities of $\beta$-glucosidase, nitroreductase, and urease enzymes had decreased compared to samples taken on day 0 for all treatments. $\beta$-glucuronidase activity did not change. Fecal $\mathrm{pH}$ and ammonia content did not change.
\end{abstract}

Conclusion: It was concluded that observed changes could have been attributed to increased milk intake; no differences could be attributed to consumption of the different CLAs.

\section{Background}

A variety of positional and geometrical isomers of linoleic acid are included in the general term conjugated linoleic acids (CLAs). Rumen bacteria produce CLAs $[1,2]$ from dietary linoleic acid, and as a result, red meats and dairy products are the main sources of cis-9, trans-11 CLA in the human diet. In foods, CLAs are in the triglyceride form. 
Experiments in which humans were fed CLAs have reported loss of body weight [3], reductions of \% body fat and sagittal abdominal diameter [3-5], and a positive impact on some coronary artery disease risk factors [6]. Various mechanisms have been presented to explain the mode of action of CLAs, either in animals or humans [49].

The gastrointestinal tract is inhabited by a large and diverse microbiota $[10,11]$. This microbial population is relatively stable, but changes occur due to age, disease status, use of medications such as antibiotics, and diet [1214]. It has been speculated that changes to the intestinal microbiota could explain alterations in lipid metabolism $[15,16]$. In vitro experiments have shown that CLAs can inhibit growth of some bacteria and alter bacteria membrane lipid composition [17]. However, very few studies have been published in which the effects of the lipid component of the diet on the gastrointestinal (GI) tract microbiota have been reported [18-20].

It is believed that the microbiota that inhabits the GI tract influences a wide variety of digestive, metabolic, and immune functions [21]. Carman et al. [22] pointed out that changes in the intestinal microflora population may not be easy to achieve, but in any case, it is changes in 'microflora associated characteristics' (MACs) that are better indicators of effects of diet on the host. A change in enzymatic activity may be one MAC that has long term implications on health. The activities of various fecal enzymes have been reported to be influenced by dietary fat [23], carbohydrates [23-27], and consumed bacteria $[25,28,29]$.

$\beta$-glucuronidase activity in feces comes from Bacteriodes and other bacteria. $\beta$-glucuronidase hydrolyzes a variety of glucuronides, liberating carcinogenic aglycones. Fecal $\beta$-glucosidase activity also comes mainly from Bacteriodes, but many streptococci and lactobacilli also have high $\beta$ glucosidase activity. $\beta$-glucosidase is responsible for the hydrolysis of plant $\beta$-glycosides, releasing into the intestinal lumen aglycones which are mutagenic and carcinogenic [30-32]. Nitroreductase enzyme acts on aromatic nitro-compounds resulting in the formation of harmful amines [33]. Urease enzyme can act on urea releasing ammonia and carbon dioxide; high urease activities have been found in some Eubacteria and Peptococcus bacteria [34]. Ammonia has been shown to promote the growth of tumors in the colon; it facilitates the growth of pathogenic bacteria and contributes to mucosal tissue damage [35]. Decreases in fecal $\beta$-glucuronidase, $\beta$-glucosidase, nitroreductase and urease activities are thus considered desirable because of their links to the production of carcinogens [36].
Goldin \& Gorbach [37] reported that fecal $\beta$-glucuronidase, nitroreductase and azoreductase enzyme activities did not change when human subjects consumed $500 \mathrm{ml}$ of low fat milk per day for 30 days. Conversely, in one Yakult feeding trial reported by Tanaka [38], $\beta$-glucuronidase enzyme activity decreased in 4 of 10 control subjects, $\beta$-glucosidase enzyme activity decreased in 3 of 10 control subjects, and reductase enzyme activity decreased in 3 of 10 control subjects consuming unfermented milk (240 $\mathrm{ml} /$ day) compared to pre-experiment values. In a second trail, the reductions of $\beta$-glucuronidase and $\beta$-glucosidase were statistically significant in subjects consuming unfermented milk (300 ml/day). Feeding lactose $(20 \mathrm{~g} /$ day or $40 /$ day) did not affect fecal $\beta$-glucosidase or $\beta$-glucuronidase activities in elderly subjects [24].

Lactobacilli along with bifidobacteria have received much attention as ingredients in probiotic products [39-41]. Feeding milk containing lactobacilli has been shown to successfully increase lactobacilli numbers [42,43]. However, feeding just lactose $20 \mathrm{~g} /$ day or $40 \mathrm{~g} /$ day has been shown to reduce significantly lactobacilli numbers [24].

It is apparent that CLAs are potent bioactive lipid ingredients in many foods. As CLAs pass down through the GI tract, they may be bringing about changes to the intestinal microbiota, which may in turn be contributing to their whole body effects.

This study was undertaken to determine whether the consumption of CLAs effected the intestinal microbiota population composition and function. Fecal samples were collected from subjects who had consumed different forms and amounts of CLA to determine whether the consumption of the experimental milks affected the numbers of various fecal bacteria, fecal enzyme activity or fecal composition. Data presented here were obtained during a larger experiment in which the effects of CLA consumption on lipid metabolism and body composition were studied.

\section{Methods \\ Subject selection}

Selection criteria for subjects in the study were: moderately hyperlipidemic (LDL cholesterol > $2.5 \mathrm{mmol} / \mathrm{L}$ ), overweight (BMI 25-30 kg/m²) men and women between the ages of 30 and 60 . Volunteers with thyroid disease, diabetes mellitus, kidney disease, or liver disease, who smoked, who had previous symptoms of lactose intolerance, consumed large amounts of alcohol or who were taking antibiotics were excluded.

Twice during the experiment, subjects filled out a questionnaire to determine their normal consumption of milk and dairy products. 


\section{Milk samples}

Three types of milk were used in the feeding trial: $4 \%$ fat homogenized cows' milk, containing $5 \mathrm{mg} / \mathrm{g}$ fat cis-9, trans-11 CLA (CONT); 4\% fat homogenized cows' milk naturally enriched in cis-9, trans-11 CLA (32 mg/g fat) by feeding cows with sunflower oil (NAT) or $4 \%$ fat homogenized cows' milk that was enriched with trans-10, cis-12 CLA (32 mg/g fat) and cis-9, trans-11 CLA (32 mg/g fat) in the form of triglycerides (Natural Co., Norway), (SYN).

For the analysis of milk fatty acids, methyl esters were prepared by base-catalyzed transmethylation according to the method of Chouinard et al.[44]. Fatty acid analyses were carried out with a gas chromatograph (HP 5890A Series II, Hewlett Packard, Palo Alto, CA) equipped with a 100-m CP-Sil 88 capillary column (i.d., $0.25 \mathrm{~mm}$; film thickness, $0.20 \mu \mathrm{m}$; Chrompack, Middelburg, the Netherlands) and a flame ionization detector. At the time of the sample injection the column temperature was $80^{\circ} \mathrm{C}$ for 1 min, then ramped at $2^{\circ} \mathrm{C} / \mathrm{min}$ to $215^{\circ} \mathrm{C}$ and maintained for $30 \mathrm{~min}$. Inlet and detector temperatures were $220^{\circ} \mathrm{C}$ and $230^{\circ} \mathrm{C}$, respectively. The split ratio was $100: 1$. The flow rate for hydrogen carrier gas was $1 \mathrm{~mL} / \mathrm{min}$. Fatty acid peaks were identified, quantified and the gas chromatograph calibrated using pure methyl ester standards ( $\mathrm{Nu}$ Chek Prep, Elysian, MN).

\section{Experimental design}

The experiment was a three feeding phase ( 8 weeks each), cross-over design separated by 2 washout periods (4 weeks each). The single-blind clinical trial was carried out at the Mary Emily Clinical Research Unit, McGill University. In each feeding phase, one third of the subjects consumed either $1 \mathrm{~L}$ /day of CONT, NAT or SYN. The type of experimental milk consumed was changed in each feeding phase, until all subjects had consumed all three milks. Milk samples were coded; subjects did not know the code. Fecal samples were collected on days 0 and 56 of each feeding phase. All samples were identified by subject number only until analyses were complete.

\section{Microbiological analyses}

Fecal samples were immediately refrigerated after collection and then they were mixed with a storage solution ( $\mathrm{pH}$ 7.2) consisting of (per L): $1 \mathrm{~g}$ yeast extract, $1 \mathrm{~g}$ $\mathrm{KH}_{2} \mathrm{PO}_{4}, 0.15 \mathrm{~g} \mathrm{~K}_{2} \mathrm{HPO}_{4}, 0.15 \mathrm{~g} \mathrm{NHCl}, 1 \mathrm{~g} \mathrm{NaCl}, 0.6 \mathrm{~g}$ $\mathrm{MgCl}_{2} 6 \mathrm{H}_{2} \mathrm{O}, 0.1 \mathrm{~g} \mathrm{KCl}$, and $0.5 \mathrm{~g}$ cysteine- $\mathrm{HCl}$, and stored at $-20^{\circ} \mathrm{C}$ until enumeration.

Aliquots of diluted fecal samples were spread on the following aqueous agar media: Columbia blood agar (CBA) media (Oxoid Company, Basingstoke, UK) containing 5\% sterile defibrinated blood (Quélab, Montreal, QC, Canada) incubated for total anaerobes; Columbia agar base (BBL, Becton Dickinson, Cockeysville, MD, USA)
$950 \mathrm{~mL}$ containing lactose $5 \mathrm{~g} / \mathrm{L}$ and cysteine hydrochloride $0.5 \mathrm{~g} / \mathrm{L}$ and $50 \mathrm{~mL}$ NPNL stock containing neomycin (Sigma, St. Louis, MO, USA) $100 \mathrm{mg} / \mathrm{L}$, paromomycin sulphate (Sigma) $200 \mathrm{mg} / \mathrm{L}$ for bifidobacteria; $500 \mathrm{~mL}$ Difco Lactobacilli MRS broth (Becton Dickenson Co., Sparkes MD, USA) containing cysteine hydrochloride $0.5 \mathrm{~g} / \mathrm{L}$, bromocresol green (Sigma) $0.05 \mathrm{~g} / \mathrm{L}-\mathrm{pH} 5.0,10 \mathrm{~mL}$ vancomycin hydrochloride (Sigma) solution, $500 \mathrm{~mL}$ agar (Difco, Detroit, MI) $40 \mathrm{~g} / \mathrm{L}$ for lactobacilli; MacConkey agar (Difco) for enterobacteriaceae; m-Enterococcus agar (Difco) for enterococci and streptococci; sulphite polymyxin milk (SPM) agar $930 \mathrm{~mL}$ containing tryptone (Difco) $15 \mathrm{~g} / \mathrm{L}$, yeast extract (Difco) $10 \mathrm{~g} / \mathrm{L}$, ferric citrate (Sigma) $0.5 \mathrm{~g} / \mathrm{L}$, agar (Difco) $18 \mathrm{~g} / \mathrm{L}, 5 \mathrm{~mL} 5 \% \mathrm{Na}_{2} \mathrm{SO}_{3}, 10$

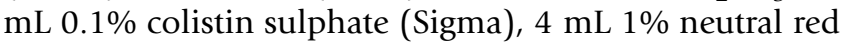
solution (supplier), $50 \mathrm{~mL}$ sterile whole cows' milk for clostridia; Schaedler agar (Becton Dickinson, Sparks, MD) for total aerobes. Microbial data were expressed as log $\mathrm{CFU} / \mathrm{g}$ wet feces.

\section{Enzyme assays}

Thawed fecal samples were homogenized (Basic T25; IKA Co., Wilmington, NC, USA) in phosphate buffer $(0.1 \mathrm{M}$; pH 7.0), sonicated $2 \times 1 \mathrm{~min}$ (Branson Sonicator Model 2210) and centrifuged $15 \mathrm{~min}$ at $500 \times \mathrm{g}$ (Dynac II, Becton Dickinson). The supernatant was used for enzyme assays.

$\beta$-Glucuronidase (EC 3.2.1.31; substrate phenolphthalin mono $\beta$-D-glucuronic acid; Sigma, St. Louis, MO), $\beta$-glucosidase (EC 3.2.1.21; substrate $p$-nitrophenyl- $\beta$-D glucopyranoside; Sigma) and nitroreductase (substrate $m$ nitrobenzoic acid; Sigma) enzyme activities were measured in fecal extracts using the methods detailed by Goldin \& Gorbach [45]. The nitroreductase assays were carried out in an anaerobic chamber. Urease (EC 3.5.1.5; substrate urea) activity was measured using the method of Ling et al.[46].

The protein concentration of fecal extracts used in enzymatic assays was determined using the method of Lowry (Sigma), with bovine serum albumin as a standard. All enzyme activities were expressed in units of product produced/mg fecal protein/min.

\section{Fecal composition analyses}

The $\mathrm{pH}$ of fecal slurry samples $(1 \mathrm{~g}$ feces, $10 \mathrm{~mL}$ distilled water, mixed with a tissue homogenizer [IKA Labortechnik, Wilmington, NC], $1 \mathrm{~min}$ ) was measured using a Accumet Model 25 pH meter (Fisher Scientific, Nepean, ON, Canada), and an Orion $\mathrm{pH}$ probe (Fisher Scientific). Ammonia concentrations of the fecal enzyme supernatant samples were measured using an Orion Ammonia probe (Fisher Scientific). The short chain fatty acid (SCFA) content of water extracts of fecal material were measured using HPLC techniques [47]. Peaks were identified by 
Table I: Milk fat content and fatty acid profile of experimental milks

\begin{tabular}{|c|c|c|c|}
\hline & \multicolumn{3}{|c|}{ Experimental Milk } \\
\hline & CONT & NAT & SYN \\
\hline Milk fat content, $\%$ & 3.9 & 3.9 & 4.0 \\
\hline \multicolumn{4}{|l|}{ Fatty acid, $\%$ by weight } \\
\hline C4:0 & 4.99 & 4.44 & 4.07 \\
\hline C6:0 & 2.45 & 1.93 & 2.18 \\
\hline C8:0 & 1.40 & 1.00 & 1.28 \\
\hline $\mathrm{Cl0} 0$ & 2.93 & 1.87 & 2.70 \\
\hline $\mathrm{Cl} 2: 0$ & 3.31 & 2.09 & 3.02 \\
\hline $\mathrm{Cl} 4: 0$ & 10.79 & 8.41 & 10.14 \\
\hline Cl4:I cis-9 & 1.07 & 0.94 & 0.99 \\
\hline CI5:0 & 1.17 & 1.00 & 1.07 \\
\hline $\mathrm{Cl} 6: 0$ & 32.42 & 20.47 & 31.18 \\
\hline CI6:I cis-9 & 1.64 & 1.06 & 1.50 \\
\hline $\mathrm{CI} 7: 0$ & 0.58 & 0.47 & 0.52 \\
\hline C18:0 & 9.46 & 13.00 & 8.97 \\
\hline $\mathrm{CI}$ : I trans- $6+$ trans $-7+$ trans -8 & 0.30 & 0.82 & 0.26 \\
\hline CI8:I trans-9 & 0.23 & 0.71 & 0.23 \\
\hline CI8:I trans- 10 & 0.34 & 1.19 & 0.33 \\
\hline CI8:I trans-II & 0.92 & 7.17 & 0.77 \\
\hline CI8:I trans- 12 & 0.49 & 1.53 & 0.45 \\
\hline CI8:I cis-II & 0.85 & 0.65 & 0.82 \\
\hline Cl8:1 cis- 12 & 0.27 & 1.39 & 0.26 \\
\hline CI8:I cis- 13 & 0.10 & 0.10 & 0.09 \\
\hline $\mathrm{Cl}$ 8:I trans- $16+$ cis- 14 & 0.34 & .066 & 0.30 \\
\hline Cl8:I cis-15 & 0.09 & 0.27 & 0.07 \\
\hline CI8:2 trans- 11 , cis- 15 & 0.10 & 0.24 & 0.13 \\
\hline CI8:2 cis- 9 , cis- 12 & 1.87 & 2.23 & 2.04 \\
\hline C20:0 & 0.14 & 0.16 & 0.16 \\
\hline CI8:3 cis-9, cis- 12, cis- 15 & 0.38 & 0.38 & 0.39 \\
\hline CI8:2 cis-9, trans-II & 0.42 & 2.92 & 3.28 \\
\hline $\mathrm{Cl} 8: 2$ trans- 10, cis- 12 & n.d.' & n.d. & 3.03 \\
\hline I. n.d. $=$ not detected & & & \\
\hline
\end{tabular}

comparing retention times to authentic standards purchased from Sigma Chemical Co. (St. Louis, USA).

\section{Ethics}

Informed consent was obtained in writing from all subjects prior to the start of the experiment. The experimental protocol was approved by the McGill University Ethics Committee.

\section{Statistical analyses}

Data were used only when samples from both day 0 and day 56 of a feeding phase were analysed. Analyses of variance (ANOVA) were carried out using the PROC GLM procedure of SAS version 8.02, with milk type (CONT, NAT, SYN), sample day ( 0 or 56) - main effects, and interactions included in the model. Microbial counts and $\mathrm{pH}$ data were analysed as actual counts and hydrogen ion concentration respectively; data in tables and graphs are the log transforms. Inability to produce a sample and con- tamination (by urine) reduced the number of samples analysed. Legends to tables and figures indicate number of data points contributing to each mean.

Since the initial ANOVA showed no CLA treatment effects, post facto the data from the three CLA milk groups (CONT, NAT, SYN) at day 0 and at day 56 were combined, and an ANOVA on the combined data performed (COMBINED DATA).

\section{Results}

Table 1 shows the fatty acid compositions of the milks that were fed. The CONT milk had the lowest levels of cis9, trans-11 CLA, and no trans-10, cis-12 CLA, while the SYN milk had the highest levels of these two fatty acids.

Fifteen subjects successfully finished the entire experiment. Three subjects dropped out mid-way through the interventions. Two subjects, one female and a male, dis- 
Table 2: Fecal microbiological profile' of subjects at Days 0 and 56 of consuming experimental milks

\begin{tabular}{|c|c|c|c|c|c|}
\hline \multirow[b]{2}{*}{ Bacteria } & \multirow[b]{2}{*}{ Day 0} & \multirow[b]{2}{*}{ Day 56} & \multicolumn{3}{|c|}{ Statistical Analyses } \\
\hline & & & Milk Type $^{2}$ & $\underline{\text { Sample Day }} \underline{\underline{3}}$ & $\underline{\mathrm{MT} * \mathrm{SD}} 4$ \\
\hline Total Aerobes & & & NS & NS & NS \\
\hline CONT & 8.62 & 8.56 & & & \\
\hline NAT & 8.50 & 8.54 & & & \\
\hline SYN & 8.48 & 8.53 & & & \\
\hline Total Anaerobes & & & NS & NS & NS \\
\hline CONT & 9.59 & 10.41 & & & \\
\hline NAT & 11.17 & 10.72 & & & \\
\hline SYN & 9.50 & 10.30 & & & \\
\hline Lactobacilli & & & NS & **** & NS \\
\hline CONT & 6.89 & 5.24 & & & \\
\hline NAT & 6.52 & 4.99 & & & \\
\hline SYN & 8.07 & 5.10 & & & \\
\hline Bifidobacteria & & & NS & $* * *$ & NS \\
\hline CONT & 7.07 & 6.44 & & & \\
\hline NAT & 7.06 & 6.23 & & & \\
\hline SYN & 7.00 & 6.25 & & & \\
\hline Enterobacteria & & & NS & NS & NS \\
\hline CONT & 7.52 & 5.75 & & & \\
\hline NAT & 8.40 & 5.39 & & & \\
\hline SYN & 7.05 & 5.37 & & & \\
\hline Entero+Strep & & & NS & NS & NS \\
\hline CONT & 7.28 & 4.92 & & & \\
\hline NAT & 6.03 & 4.76 & & & \\
\hline SYN & 6.43 & 5.32 & & & \\
\hline Clostridia & & & NS & NS & NS \\
\hline CONT & 4.84 & 5.04 & & & \\
\hline NAT & 5.04 & 5.12 & & & \\
\hline SYN & 4.91 & 4.97 & & & \\
\hline
\end{tabular}

I. bacteria counts expressed as log CFU/g wet feces

2. difference due to milk type (CONT vs NAT vs SYN)

3. difference due to sample day (DAY 0 vs DAY 56)

4. interaction - milk type and sample day

continued during the first phase of the clinical trial because of personal reasons. Another female subject discontinued during the second phase of the clinical trial because of pregnancy. Compliance was tested by asking the subjects to return the used and unused milk containers.

The two surveys questioning milk product consumption that were carried out during the course of the experiment (data not presented) indicated that all of the subjects had low daily intakes of milk (skim, 1\% fat, 2\% fat, whole milk) and dairy products (butter, cheese, yogurt, icecream, dairy creamers) as part of their normal diet. During the CLA-milk part of the experiment, subjects were consuming an additional litre of milk per day.
Table 2 is a summary of the microbial analyses of fecal samples collected on days 0 and 56 of the three feeding phases. Within each diet group, there were large inter-subject variations for the enumerated bacteria. Generally, samples contained more total anaerobes than aerobes. ANOVA analyses indicated that the type of milk consumed did not have any effect on the fecal microbial profiles. At the end of the 56 day feeding phases, there were no statistical differences in the number of fecal total aerobes, total anaerobes, enterobacteria and entrococci + streptococci and clostridia compared to the numbers enumerated in samples taken at day 0 . However, at the end of 56 days, fecal samples contained significantly fewer lactobacilli and bifidobacteria compared to samples taken at day 0 . 


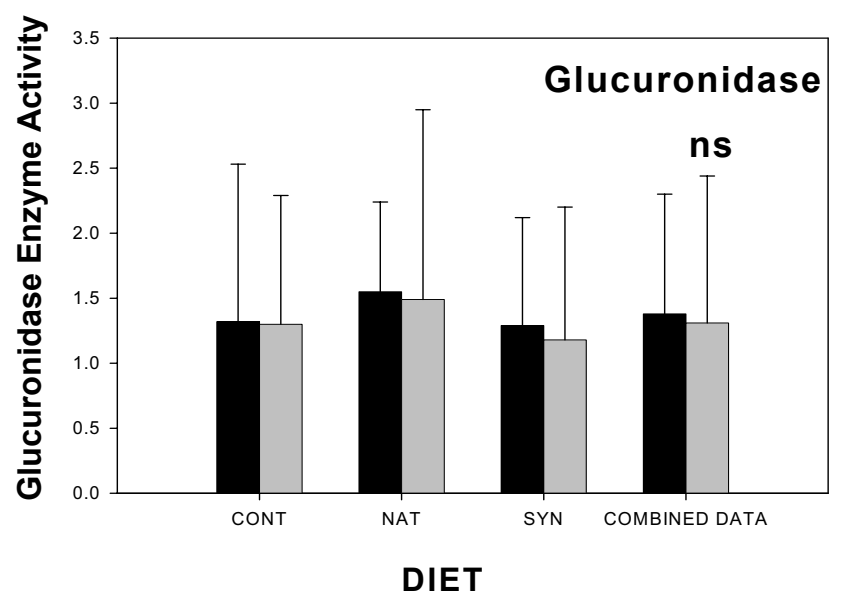

$\square=$ Day 0 data; $\square=$ Day 56 data. $n s=$ not significantly different; $\mathrm{p}>0.05$

Figure I

Fecal glucuronidase enzyme activity in subjects consuming milk containing $5 \mathrm{mg} / \mathrm{g}$ fat cis-9, trans- I CLA - CONT; 32 $\mathrm{mg} / \mathrm{g}$ fat cis-9, trans-I I CLA - NAT; $32 \mathrm{mg} / \mathrm{g}$ fat trans- 10 , cis12 CLA (32 mg/g fat) and cis-9, trans-I I CLA - SYN. Number of samples contributing to mean $=12$. Data from the 3 different milk groups (CONT, NAT, SYN) for Day 0 and Day $56=$ COMBINED DATA. Number of samples contributing to mean $=36$. Enzyme activity units $-\mathrm{mg}$ phenolphthalein produced $/ \mathrm{min} / \mathrm{mg}$ fecal protein.

The results of the fecal enzyme analyses are shown in Figures 1, 2, 3, 4. The enzyme activity for each CLA milk group (CONT, NAT, SYN) is plotted showing values for samples from day 0 and day 56 . When ANOVA analyses indicated that there were no statistical differences between any of the different CLA milk groups, all milk group data were combined, and the results of sampling day ( 0 vs 56) are shown in the fourth pair of bars (COMBINED DATA). This combining of the data had the advantage of increasing the statistical power of the ANOVA test. The activities of $\beta$-glucosidase, reductase, and urease in fecal material all significantly declined in samples obtained at day 56 of the feeding phase, compared to samples obtained at day 0 when the COMBINED DATA were analysed. There was no change in fecal $\beta$-glucuronidase activity over time.

Fecal pH was not affected by either the kind of CLA milk consumed or the sampling day ( 0 vs 56). The average $\mathrm{pH}$ of all groups was between 7.1 and 7.5. Likewise, ammonia levels measured in fecal samples were not different in subjects consuming different CLA milks or between samples taken at days 0 and 56. Average fecal ammonia concentrations levels ranged from $2-6 \mathrm{mM} / \mathrm{mL}$ of fecal extract.

HPLC analyses of fecal samples obtained at day 0 and day 56 of the feeding periods contained acetic acid, propionic acid, butyric acid, and isobutyric acid. The small number of samples analysed prevented rigorous statistical analyses. At day 0 , only $50 \%$ of the samples analysed contained measurable amounts of lactic acid, but $100 \%$ of 56 day samples from the same subjects contained lactic acid.

\section{Discussion}

The make-up of the microbial population that inhabits the human GI tract is influenced by several factors including diet and diet constituents $[11,12,22]$. Bifidobacteria have been the subject of much research because of the belief that they are probiotic bacteria, and therefore dietary components should be identified that increase bifidobacteria numbers [47-50]. Several studies have shown that significant changes (increases) in fecal bifidobacteria numbers can be achieved by the addition of fructans to the diet [24,51-54].

In our study where subjects were consuming an additional $1 \mathrm{~L}$ of milk per day, bifidobacteria numbers significantly declined in all three diet groups over the course of the 56 day feeding phases, perhaps indicating that milk per se is affecting this family of bacteria. This is supported by Tanaka [38] who reported bifidobacteria numbers declined (compared to pre-experiment values) in 4 of 10 and 5 of 10 control subjects who were receiving $240 \mathrm{~mL} / \mathrm{d}$ and 300

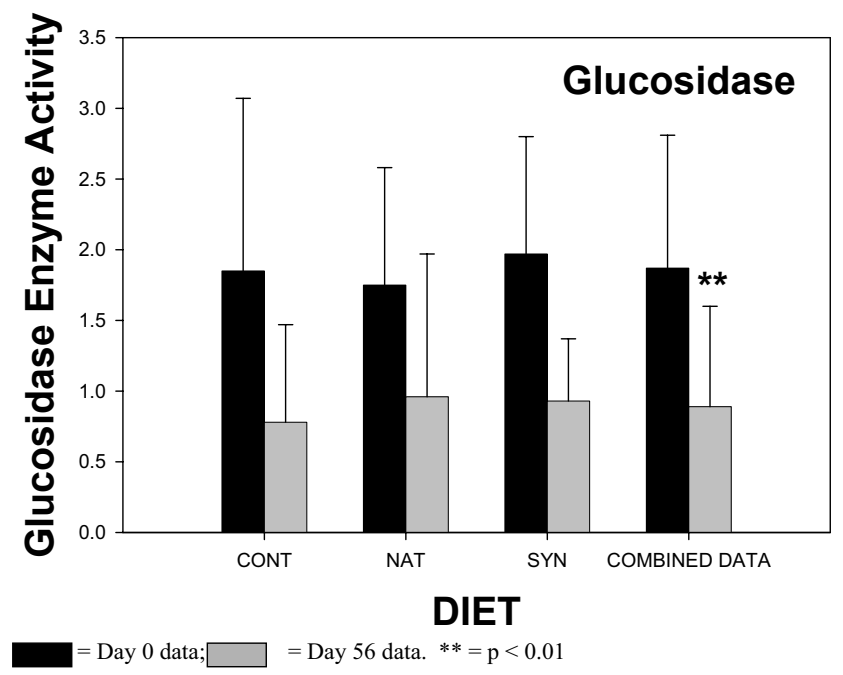

Figure 2

Fecal glucosidase enzyme activity in subjects consuming milk containing $5 \mathrm{mg} / \mathrm{g}$ fat cis-9, trans- II CLA - CONT; $32 \mathrm{mg} / \mathrm{g}$ fat cis-9, trans- II CLA - NAT; $32 \mathrm{mg} / \mathrm{g}$ fat trans-10, cis- 12 CLA (32 mg/g fat) and cis-9, trans-I I CLA - SYN. Number of samples contributing to mean $=1 \mathrm{I}$. Data from the 3 different milk groups (CONT, NAT, SYN) for Day 0 and Day $56=$ COMBINED DATA. Number of samples contributing to mean $=33$. Enzyme activity units $-\mathrm{mg} p$-nitrophenol produced $/ \mathrm{min} / \mathrm{mg}$ fecal protein. 


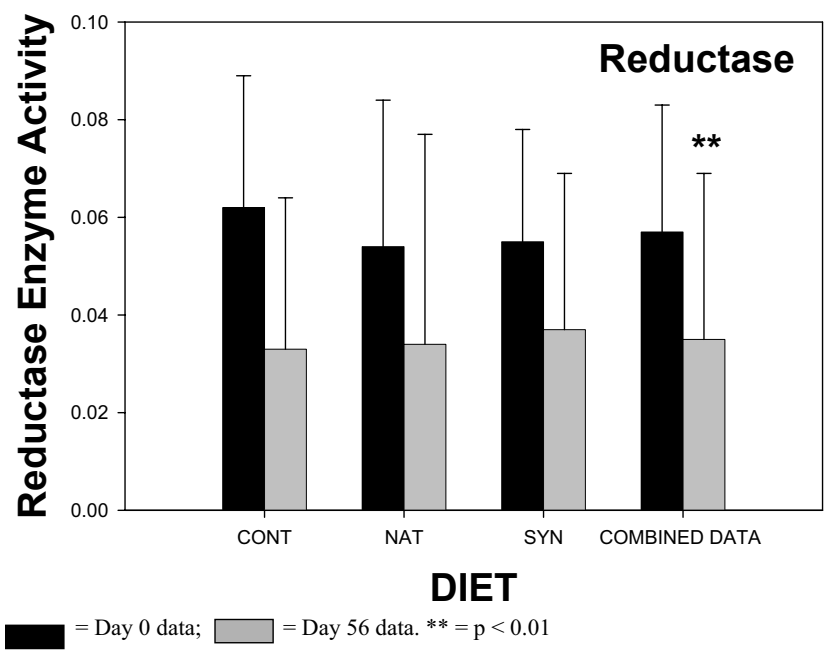

Figure 3

Fecal nitroreductase enzyme activity in subjects consuming milk containing $5 \mathrm{mg} / \mathrm{g}$ fat cis-9, trans-I I CLA - CONT; 32 $\mathrm{mg} / \mathrm{g}$ fat cis-9, trans-II CLA - NAT; $32 \mathrm{mg} / \mathrm{g}$ fat trans- 10 , cisI 2 CLA (32 mg/g fat) and cis-9, trans- I I CLA - SYN. Number of samples contributing to mean $=8$. Data from the 3 different milk groups (CONT, NAT, SYN) for Day 0 and Day $56=$ COMBINED DATA. Number of samples contributing to mean $=24$. Enzyme activity units - ug $m$-aminobenzoic acidproduced $/ \mathrm{min} / \mathrm{mg}$ fecal protein.

$\mathrm{mL} / \mathrm{d}$ (respectively) of unfermented milk. In addition, we also found that lactobacilli numbers significantly declined, which may have been the result of the consumption of an additional $48 \mathrm{~g}$ lactose/day during the experiment.

In this experiment, where adult subjects consumed an additional $1 \mathrm{~L}$ of milk during the feeding portions of the experiment, $\beta$-glucosidase, nitroreductase and urease activities were all significantly decreased. These effects on fecal enzyme activities occurred in subjects who normally consumed low levels of milk and dairy products. It is not possible at this time to attribute changes in fecal enzyme activity to the changes in the population of one or more fecal bacteria. However, the long term effects of reducing the activities of these enzymes in particular may be desirable.

A reduction in the $\mathrm{pH}$ of intestinal digesta has been reported to be desirable [55]. Some feeding trials have reported a lowering of fecal $\mathrm{pH}$ [20] but, as we have reported here, other studies have found no changes in fecal pH due to changes in diet $[24,26,56]$. The use of fecal $\mathrm{pH}$ as an indicator of fermentation and acidity in the colon has been questioned [26].

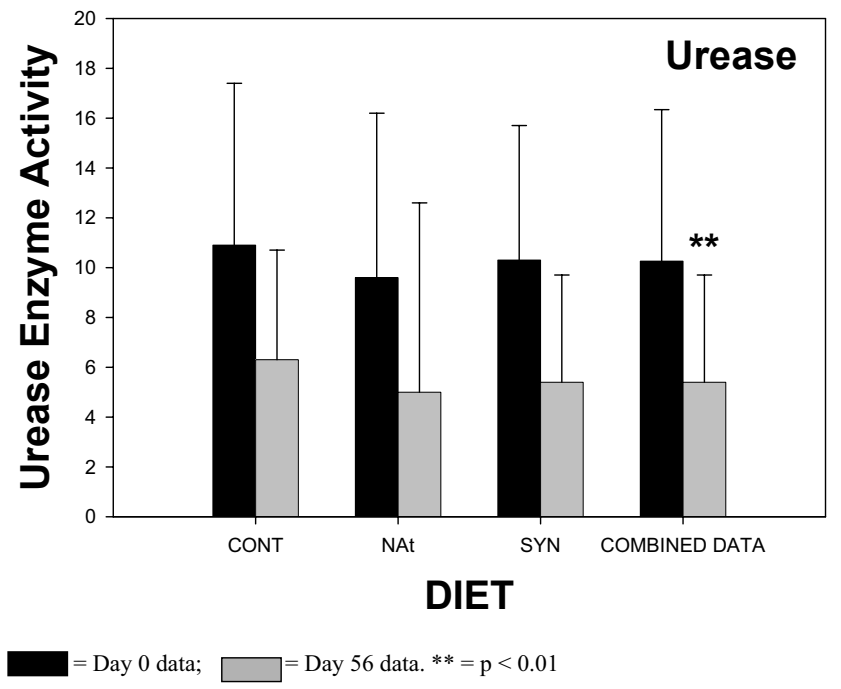

Figure 4

Fecal urease enzyme activity in subjects consuming milk containing $5 \mathrm{mg} / \mathrm{g}$ fat cis-9, trans- I I CLA - CONT; $32 \mathrm{mg} / \mathrm{g}$ fat cis-9, trans-II CLA - NAT; $32 \mathrm{mg} / \mathrm{g}$ fat trans-10, cis- 12 CLA (32 mg/g fat) and cis-9, trans- I I CLA - SYN. Number of samples contributing to mean $=12$. Data from the 3 different milk groups (CONT, NAT, SYN) for Day 0 and Day $56=$ COMBINED DATA. Number of samples contributing to mean $=36$. Enzyme activity units - mmoles ammonia produced $/ \mathrm{min} / \mathrm{mg}$ fecal protein.

Ammonia in not usually found in high concentrations in fecal material, because any ammonia generated in the intestinal lumen from bacterial breakdown of nitrogenous substances - proteins, urea - is normally quickly absorbed. High levels of intestinal ammonia are not desirable, and it has been shown that the bacterial production of ammonia can be reduced by lowering the $\mathrm{pH}$ or adding lactose, glucose or lactulose to the fermentation media [57]. In our subjects, the reduction of the activity of fecal urease did not result in lowered fecal ammonia concentrations.

The effects observed in this feeding trial could be attributed to the increased consumption of milk. At this time, it is not possible say what component of milk caused the observed effects. Our data indicate that consumption of milks with different types and levels of CLAs do not change the intestinal microbiota composition or function. Changes in fecal enzyme activity due to increased milk consumption may have long term health benefits.

\section{Acknowledgements}

Presented in part at the $18^{\text {th }}$ International Congress of Nutrition, Durban, 2005. Funding for this experiment was provided by Agriculture and Agrifood Canada CARD Program and the Dairy Farmers of Canada. 


\section{References}

I. Kepler CR, Tove SB: Biohydrogenation of unsaturated fatty acids. J Biol Chem 1967, 242:5686-5692.

2. Hughes PE, Hunter WJ, Tove SB: Biogeneration of unsaturated fatty acids. J Biol Chem 1982, 257:3643-3649.

3. Gaullier J-M, Halse J, Hoye K, Kristiansen K, Fagertun H, Vik H, Gudmundsen O: Conjugated linoleic acid supplementation for I y reduces body fat mass in healthy overweight humans. $\mathrm{Am} J$ Clin Nutr 2004, 79: I I I 8-I I 25.

4. Risérus U, Berglund L, Vessby B: Conjugated linoleic acid (CLA) reduced abdominal adipose tissue in obese middle-aged men with signs of the metabolic syndrome: a randomized controlled trial. Internat J Obesity 2001, 25: I I29-II35.

5. Smedman A, Vessy B: Conjugated linoleic acid supplementation in humans - metabolic effects. Lipids 200I, 36:773-78I.

6. Noone EJ, Roche HM, Nugent AP, Gibney MJ: The effect of dietary supplementation using isomeric blends of conjugated linoleic acid on lipid metabolism in healthy human subjects. Br J Nutr 2002, 88:243-25I.

7. Park Y, Albright KJ, Liu W, Storkson JM, Cook ME, Pariza MW: Effect of conjugated linoleic acid on body composition in mice. Lipids 1997, 32:853-858.

8. Ostrowska E, Muralitharan M, Cross RF, Bauman DE, Dunshea FR: Dietary conjugated linoleic acids increase lean tissue and decrease fat deposition in growing pigs. J Nutr 1999, I 29( I I ):2037-2042.

9. Wahle KWJ, Heys SD, Rotondo D: Conjugated linoleic acids: are they beneficial or detrimental to health? Prog Lipid Res 2004, 43:553-587.

10. Finegold SM, Sutter VL, Mathisen GE: Normal indigenous flora. In Human Intestinal Microflora in Health and Disease New York: Academic Press; |983:3-3|.

II. Wilson KH: The Gastrointestinal biota. In Textbook of Gastroenterology Volume I. 3rd edition. Edited by: Yamada T. Philadelphia: Lippincott, Williams and Wilkins; 1999:624-636.

12. Mallett AK, Rowland IR: Factors affecting the gut microflora. In Role of the Gut Flora in Toxicity and Cancer New York: Academic Press; 1988:347-382.

13. Mitsuoka T: Intestinal flora and aging. Nutr Rev 1992, 50:438-446.

14. Gorbach SL: Perturbation of intestinal microflora. Vet Human Toxicol 1993, 35(suppl I): I5-23.

15. Van Loo JAE: Prebiotics promote good health, the basis, the potential, and the emerging evidence. J Clin Gastroenterol 2004, 38(supp 2):S70-S75.

16. Delzenne NM, Williams CM: Prebiotics and lipid metabolism. Curr Opinion Lipid 2002, 1 3:6 I-67.

17. Jenkins K, Courtney PD: Lactobacillus growth and membrane composition in the presence of linoleic or conjugated linoleic acid. Can J Microbiol 2003, 49:5 I-57.

18. Cummings JH, Wiggins HS, Jenkins DJA, Houston $H$, Jivraj T, Drasar BS, Hill MJ: Influence of diets high and low in animal fat on bowel habit, gastrointestinal transit time, fecal microflora, bile acid, and fat excretion. J Clin Invest 1978, 6 I:953-963.

19. Endo K, Kumemura M, Nakamura K, Fujisawa T, Suzuki K, Benno Y, Mitsuoka T: Effect of high cholesterol diet and polydextrose supplementation on the microflora, bacteria enzyme activity, putrefactive products, volatile fatty acid (VFA) profile, weight, and $\mathrm{pH}$ of the feces in healthy volunteers. Bifidobacteria Microflora 1991, 10:53-64.

20. Eastwood MA, Allgood GS: The effect of olestra on breath gas production and faecal microbial counts. Eur J Clin Nutr 1995, 49:627-639.

21. Kneifel W, Mattila-Sandholm T, von Wright A: Probiotic bacteria detection and estimation in fermented and non-fermented dairy products. In Encyclopedia Food Micro Edited by: Batt CA, Patel PD. New York: Academic Press; 2000:1783-I789.

22. Carman RJ, Van Tassell RL, Wilkins T: Interactions between dietary compounds and the colonic microflora. In Science for the Food Industry on the 2 I st Century, Biotechnology Supercritical Fluids, Membranes and other Advanced Technologies for Low Calorie, Healthy Food Alternatives Edited by: Yalpani M. Prospect IL: ATL Press; 1993:313-342.

23. Bartram H-P, Gostner A, Kelber E, Dusel G, Weimer A, Scheppach $W$, Kasper $\mathrm{H}$ : Effects of fish oil on fecal bacterial enzymes and steroid excretion in healthy volunteers: implications for colon cancer prevention. Nutr Cancer 1996, 25:71-78.
24. Kleesen B, Sykura B, Zunft H-J, Blaut M: Effects of inulin and lactose on fecal microflora, microbial activity, and bowel habit in elderly constipated persons. Am J Clin Nutr I997, 65: $1397-1402$.

25. Freeman HJ: Effects of differing purified cellulose, pectin, and hemicellulose fiber diets on fecal enzymes in I,2-dimethylhydrazine-induced rat colon carcinogenesis. Cancer Res 1986 , 46:5529-5532.

26. Bouhnik Y, Flourie B, Andrieux C, Bisetti N, Briet F, Rambaud JC: Effects of Bifidobacterium sp fermented milk ingested with or without inulin on colonic bifidobacteria and enzymatic activities in healthy humans. Eur J Clin Nutr 1996, 50:269-273.

27. Buddington RK, Williams $\mathrm{CH}$, Chen S-C, Witherly SA: Dietary supplement of neosugar alters the fecal flora and decreases activities of some reductive enzymes in human subjects. Am J Clin Nutr 1996, 63:709-716.

28. Goldin BR, Swenson L, Dwyer J, Sexton M, Gorbach SL: Effect of diet and Lactobacillus acidophilus supplements on human fecal bacterial enzymes. J Nat Cancer Inst 1980, 64:255-26I.

29. Rambaud J-C, Bouhnik Y, Marteau P, Pochart P: Manipulation of the human gut microflora. Proc Nutr Soc 1993, 52:357-366.

30. Goldin B, Gorbach SL: Alterations in fecal microflora enzymes related to diet, age, lactobacillus supplements and dimethylhydrazine. Cancer 1977, 40:2421-2426.

3I. Carman RJ, Van Tassell RL, Wilkins T: The normal intestinal microflora: ecology, variability and stability. Vet Human Toxicol 1993, 35(Suppl I): I I- |4.

32. Nakamura J, Kubota Y, Miyaoka M, Saitoh T, Mizuno F, Benno Y: Comparison of four microbial enzymes in Clostridia and Bacteriodes isolated from human feces. Microbiol Immun 2002, 46:487-490.

33. Draser BS, Renwick AG, Williams RT: The role of the gut flora in the metabolism of cyclamate. Biochem J 1972, I 29:881-890.

34. Suzuki K, Benno Y, Mitsuoka T, Takebe S, Kobash K, Hase J: Ureaseproducing species of intestinal anaerobes and their activities. Appl Environ Microbiol 1979, 37:379-382.

35. Malin M, Verronen P, Mykkanen H, Salminen S, Isolauri E: Increased bacterial urease activity in faeces in juvenile chronic arthritis: evidence of altered intestinal microflora? Brit J Rheumatol 1996, 35:689-694.

36. Graston SM, Juntunen KS, Poutanen KS, Gylling HK, Miettinen TA, Mykkanen HM: Rye bread improves bowel function and decreases the concentrations of some compounds that are putative colon cancer risk markers in middle-aged women and men. I Nutr 2000, 130:2215-2221.

37. Goldin B, Gorbach SL: The effect of milk and lactobacillus feeding on human intestinal bacterial enzyme activity. Am J Clin Nutr 1984, 39:756-76।.

38. Tanaka R: The effects of the ingestion of fermented milk with Lactobacillus casei Shirota on the gastrointestinal microbial ecology in healthy volunteers. In Gut Microflora and Health - Past, Present and Future. International Congress and Symposium Series No. 219 Edited by: Leeds AR, Rowland IR. London: Royal Society of Medicine Press; 1997:37-45.

39. Sanders ME: Lactic acid bacteria as promoters of human health. In Functional Foods Edited by: Goldberg I. New York: Chapman and Hill Publ. Co; 1994:294-322.

40. Lee Y-K, Salminen S: The coming age of probiotics. Trends Food Sci \& Technol 1995, 6:24|-244.

4I. Isolauri E, Salminen S, Ouwehand AC: Microbial-gut interactions in health and disease. Probiotics. Best Pract Res Clin Gastroenterol 2004, 1 8:299-313.

42. Tannock GW, Munro K, Harmsen HJM, Welling GW, Smart J, Gopal PK: Analysis of the fecal microflora of human subjects consuming a probiotic product containing Lactobacillus rhamnosus DR20. Appl Environ Micro 2000, 66:2578-2588.

43. Vesa T, Pochart P, Marteau P: Parmacokinetics of Lactobacillus plantarum NCIMB 8826, Lactobacillus fermentum KLD, and Lactococcus lactis MG 1363 in the human gastrointestinal tract. Aliment Pharmacol Ther 2000, I 4:823-828.

44. Chouinard PY, Lévesque J, Girard V, Brisson GJ: Dietary soybeans extruded at different temperatures: milk composition and in situ fatty acid reactions. J Dairy Sci 1997, 80:2913-2924.

45. Goldin R, Gorbach SL: The relationship between diet and rat fecal bacterial enzymes implicated in colon cancer. J Nat Cancer Inst 1976, 57:37|-375. 
46. Ling WH, Korpela R, Mykkanen H, Salminen S, Hanninen O: Lactobacillus strain GG supplementation decreases colonic hydrolytic and reductive enzyme activities in healthy female adults. J Nutr 1994, I 24: 18-23.

47. Fernandes J, Rao AV, Wolever TMS: Different substrates and methane producing status affect short-chain fatty acid profiles produced by in vitro fermentation of human feces. J Nutr 2000, I30:1932-1936.

48. Modler HW, McKellar RC, Yaguchi M: Bifidobacteria and bifidogenic factors. Can Inst Food Sci Technol J 1990, 23:30-4I.

49. Ishibashi N, Shimamura S: Bifidobacteria: research and development in Japan. Food Technol 1993, June: I26-135.

50. Gibson GR: Dietary modulation of the human gut microflora using the prebiotics oligofructose and inulin. J Nutr 1999, I29:|438S-I44IS

5I. Bielecka M, Biedrzycka E, Majkowska A: Selection of probiotics and prebiotics for synbiotics and confirmation of their in vivo effectiveness. Food Res Internat 2002, 35:|25-|3|.

52. Roberfroid MB, Van Loo JAE, Gibson GR: The bifidogenic nature of chicory inulin and its hydrolysis products. J Nutr 1998, I 28: I1-19.

53. Kruse H-P, Kleessen B, Blaut M: Effects of inulin on faecal bifidobacteria in human subjects. Br J Nutr 1999, 82:375-382.

54. Tuohy KM, Finlay RK, Wynne AG, Gibson GR: A human volunteer study on the prebiotic effects of HP-inulin - faecal bacteria enumerated using fluorescent in situ hybridisation (FISH). Anaerobe 2001, 7:113-118.

55. Samelson SL, Nelson RL, Nyhus LM: Protective role of faecal pH in experimental colon carcinogenesis. J Royal Soc Med 1985, 78:230-233.

56. van Dokkum W, Wezendonk B, Srikumar TS, van den Heuve EGHM: Effect of nondigestible oligosaccharides on large-bowel functions, blood lipid concentrations and glucose absorption in young healthy male subjects. Eur J Clin Nutr 1999, 53:1-7.

57. Vance AJ, Burridge SM: Ammonia production by intestinal bacteria: the effects of lactose, lactulose and glucose. J Med Microbiol 1980, I3:|77-|9|

Publish with Biomed Central and every scientist can read your work free of charge

"BioMed Central will be the most significant development for disseminating the results of biomedical research in our lifetime. "

Sir Paul Nurse, Cancer Research UK

Your research papers will be:

- available free of charge to the entire biomedical community

- peer reviewed and published immediately upon acceptance

- cited in PubMed and archived on PubMed Central

- yours - you keep the copyright

Submit your manuscript here:

http://www.biomedcentral.com/info/publishing_adv.asp
BioMedcentral 